This item was submitted to Loughborough's Research Repository by the author.

Items in Figshare are protected by copyright, with all rights reserved, unless otherwise indicated.

\title{
Family business survival and the role of boards
}

PLEASE CITE THE PUBLISHED VERSION

http://dx.doi.org/10.1111/etap.12071

\section{PUBLISHER}

John Wiley \& Sons, Inc. @ Baylor University

\section{VERSION}

AM (Accepted Manuscript)

\section{PUBLISHER STATEMENT}

This work is made available according to the conditions of the Creative Commons Attribution-NonCommercialNoDerivatives 4.0 International (CC BY-NC-ND 4.0) licence. Full details of this licence are available at: https://creativecommons.org/licenses/by-nc-nd/4.0/

\section{LICENCE}

CC BY-NC-ND 4.0

\section{REPOSITORY RECORD}

Wilson, Nick, Mike Wright, and Louise Scholes. 2019. "Family Business Survival and the Role of Boards". figshare. https://hdl.handle.net/2134/19962. 


\title{
Family Business Survival and the Role of Boards
}

\author{
Nick Wilson \\ Credit Management Research Center \\ Leeds University Business School \\ Tel: +44 (0)1133434472 \\ Email: nw@lubs.leeds.ac.uk
}

\author{
Mike Wright \\ Center for Management Buy-out Research \\ Imperial College Business School \\ and \\ University of Ghent \\ Tel: +44 (0)7725159873 \\ Email: mike.wright@imperial.ac.uk \\ Louise Scholes \\ Durham University Business School \\ Tel: +44 (0) 1913345876 \\ Email: louise.scholes@durham.ac.uk
}

This version, March 14, 2013

Acknowledgements: Thanks to participants at the Theories of Family Firms conference in Edmonton, May 2012 for comments on an earlier draft and to Danny Miller, Isabelle Le Breton-Miller, Eric Gedajlovic, the guest editors and two anonymous reviewers for very helpful comments. 


\title{
Family Business Survival and the Role of Boards
}

\begin{abstract}
We explore the vexed question of whether family firms are more likely to survive than nonfamily firms, focusing on the role of board composition. Utilizing a unique dataset of over 700,000 private family and non-family firms in the UK during 2007-10, we find family firms are significantly less likely to fail than non-family firms. We identify the board characteristics associated with survival/failure in all firms and determine that it is these characteristics that are important in explaining the lower failure probability of family firms. We conclude with an agenda for further research on boards and family firm survival.
\end{abstract}

\section{Introduction}

The question of whether family firms perform better than their non-family counterparts is hotly debated in the literature (Gedajlovic et al., 2012; Wright \& Kellermanns, 2011). A central aspect of family firm performance concerns survival across generations as a family firm (Yu et al., 2012). But, as Colli (2012) has pointed out, survival also relates to the longevity of the family firm as a viable entity, that is whether the firm goes bankrupt or not. Longevity in family firms varies but while the vast succession literature focuses on survival as a family firm, there is little empirical evidence on the determinants of whether family firms survive as viable entities. An extensive literature has examined differences in risk-taking behavior between family and non-family firms and the implications for performance (see e.g. Hiebl, 2013 for a review). Studies generally find that family firms are more risk averse than non-family firms. However, there is an unresolved tension in the family firm literature about these firms' approach to risk taking and the consequences for survival of the firm as a viable entity.

We explore the vexed question of whether family firms are more likely to survive than non-family firms and the determining factors. The boards of family firms play a central role in deciding upon strategy and differ from boards in non-family firms (Bammens et al., 2011; Gersick \& Feliu, 2013; Goel, Jussila \& Ikäheimonen, 2013). Accordingly, we examine 
the role of board composition as this, more than any other group, has ultimate control of the direction of the firm to ensure its survival as an independent entity.

We make the following contributions. First, we contribute by providing large-scale systematic analysis that helps resolve the question of whether family firms are more likely to survive as viable entities than non-family firms. In finding that family firms are more likely to survive as viable entities than non-family firms, we explore for the first time the determinants of this difference. Second, we begin to contribute to filling a major gap in the literature on board structures and their impact on survival rates, particularly in relation to private firms (Berrone et al., 2012). We suggest that the board compositions and characteristics that are more prevalent in or unique to family firms involve more human and social capital resources associated with lower bankruptcy risk. In other words, families can put together and maintain boards that give the firm a higher chance of survival.

\section{Literature Review}

The literature on the survival chances of family firms compared to non-family firms is ambivalent. A higher chance of survival for family firms could be expected, it is suggested, because of family-oriented goals, higher levels of social capital, survivability capital, efficiency and lower overall agency costs.

Family-oriented goals such as preserving family cohesion and socioemotional wealth (SEW) (Chrisman et al., 2003; Gomez-Mejia et al., 2007), preserving family reputation (Berrone et al., 2012), providing employment for family members (Kellermanns et al., 2008) or taking a long-term view that involves bequeathing the business to the next generations (Miller \& Le Breton-Miller, 2003) may contribute to family firms being more likely to survive than non-family firms. Since family firm failure likely results in a loss of SEW, family firms and family members will likely take actions to ensure firm survival. 
Higher levels of social capital in family firms may lead to a greater chance of survival. The unique governance properties of family firms associated with stable ownership is central to the development of non-tradable assets such as bonding and bridging social capital and reputational assets (Gedajlovic \& Carney, 2010). Accordingly, family firms may be better able to build long-standing relationships with trading partners (Arregle et al., 2007), advisors (Gersick and Feliu, 2013), financiers and outside family members. This relational capital may contribute to a higher likelihood of survival for family firms since closer partner firms may be more willing to extend credit terms in times of trading difficulty.

The unique resources of family firms have been referred to as 'familiness' and survivability capital is one of these resources (Sirmon \& Hitt, 2003). Survivability capital is the combination of the unique human, social and patient capital (i.e., long term) resources in family firms and distinguishes them significantly from non-family firms. We have already noted the contribution of the specific social capital of family firms to their survival and families with strong social capital may also be more effective at nurturing the human capital of the next generation. Survivability capital can help sustain the business during hard times, recessions or after strategic mistakes, and can therefore help explain the greater likelihood of survival among family firms compared to non-family firms.

Differences in agency costs between family and non-family firms will likely have a bearing on survival chances (Chrisman, Chua, \& Litz, 2004). Traditional agency problems in family firms will be lower than in non-family firms because of better alignment of interests. As a result, family principals would be more likely than non-family firm principals to avoid strategic choices that carry a significant risk of financial losses because family wealth is heavily tied-up in the one firm (Anderson \& Reeb, 2004).

Family firms may be more likely to survive than non-family firms due to greater efficiency. Family firms may be more efficient in part due to their propensity to be more 
parsimonious in resource use because they are funding activities with their own money (Carney, 2005). Family firms, because they rely on internal sources of financing, may scrutinize business opportunities with greater intensity and forgo inefficient unrelated diversification (Anderson \& Reeb, 2004). To the extent that family firms engage in fewer diversifying acquisitions, business risk may also be reduced and survival chances increased (Miller et al., 2010).

In contrast to these arguments, a lower chance of survival for family firms may arise from conflicts, altruism, downsides of social capital, lower levels of risk taking and lower levels of R\&D. Conflicts may be greater in family firms than in non-family firms and arise from a variety of sources such as ownership dispersion among family members, sibling rivalry, and identity conflict (Schulze et al. 2003). While some kinds of conflict can be beneficial, others can negatively impact firm performance (Kellermanns \& Eddleston, 2004). Ultimately if conflicts result in irresolvable differences about the direction of the firm they may undermine its very survival.

Altruism encompasses consideration among family members, loyalty and commitment to the family and firm. Altruism can have a damaging effect on family firm survival. For example if family firms appoint family members regardless of their ability, rather than recruiting non-family members who do have the skills, they expose themselves to costly-to-mitigate adverse selection problems (Schulze et al. 2003). Besides reducing performance, such lack of ability may mean the family firm lacks the human capital resources they need to adapt in order to survive. Further, the absence of traditional agency costs noted above may be offset by principal-principal agency problems that lead to managerial entrenchment and a failure to sanction under-performing family members, especially in private family firms (Gedajlovic et al., 2012). We have noted the potential benefits of the social capital of family firms above. However, the potential downside to family firms likely 
having long-standing trading relationships is that their social capital is more restricted. As such, where changes in environmental conditions indicate a need to develop new strategic directions to survive, existing strong ties may paradoxically undermine survival chances. Developing new weak ties may be needed but may increase risk and further reduce survival chances (Zahra, 2010).

Family firms are generally more risk averse than non-family firms (Hiebl, 2013) but actions to preserve SEW through maintaining ownership and control may undermine the survivability of the firm (Zellweger, et al., 2013). As a result, family firms may not undertake sufficient diversification when there is a need to invest in diversifying innovation to increase survival chances (Carney, 2005).

Extending this point, innovation through R\&D may be needed if firms are to respond to changing environmental conditions and ultimately survive. However, R\&D in family firms is lower compared to non-family firms (Villalonga \& Amit, 2006). Parsimony with financing may contribute to efficiency, as noted earlier, but may mean little slack is available for innovation. While established wealthy families may be reluctant to risk destroying the value of old capital in favor of new wealth formed via the creative destruction process (Morck, 2003), their reluctance to engage in R\&D may undermine the survivability of existing activities.

Overall, the literature is unclear about the expected difference between the survival of family versus non-family firms. This leaves open the question of relative survival rates and their determinants that needs to be informed by empirical analysis as offered by our data-set. The following analysis attempts to reflect these potentially positive and negative influences on whether family and non-family firms are more likely to survive through the use of variables relating to board composition (human and social capital relating to the preservation of family-oriented goals versus firm goals), financial information (risk-taking, parsimonious 
use of external debt, creditworthiness) and non-financial information (sector risk and innovativeness, diversification). Further, we adopt different definitions of family firms as robustness checks in order to take account of potential differences in firm objectives.

\section{The Data}

Our database covers the population of U.K. private companies filing accounts from 2007-2010 using data collected from Companies' House, the national data-base on limited companies, and the Insolvency Service. We include non-financial variables and variables relating to directors and their corporate history from other sources such as company registration documents and the legal process used for debt recovery. We utilize a unique dataset of over 700,000 medium and large private family and non-family firms with an annual sales turnover of at least $£ 6.5$ million (approx. $\$ 10$ million), a balance sheet total of at least $£ 3.26$ million (approx. $\$ 5$ million) or at least 50 employees. We identify over 12,500 instances of bankruptcy within the period to 2010 .

\section{The Measures}

The variables used in the analysis are described below.

\section{Survival (Exit via Legal Bankruptcy)}

We identify companies that exit via the UK's formal bankruptcy regime of administration, receivership or liquidation. These companies have been forced into closure by creditors through a legal process. Voluntary exits are excluded. A company is flagged as failed at the last reported accounts prior to the failure event year and classified as non-failed in any other period. Our period covers the peak of corporate bankruptcies associated with the first wave of the recent UK recession.

\section{Family firms}

Family firms are identified through the analysis of shareholding and directorship information of incorporated firms in the UK as filed at Companies House. A firm is 
considered a family business if the family has more than $50 \%$ of the shares of the firm, two or more shareholders have the same surname, and at least one family shareholder is also a director. A dummy variable, Family Dummy, is constructed to distinguish family from nonfamily firms. The ownership variable is the proportion of shares owned by current directors (Insider Shareholder \%). For robustness testing we refine the family firm definition to include, firstly, only those family firms where the family directors make up more than 30 percent of the board (family-firm $>30 \%$ ) and, secondly, where the family directors make up more than 50 percent of the board (family-firm >50\%) (Westhead \& Cowling, 1998). Our interest is in the sign, significance and magnitude of the family dummy variables in the presence of various combinations of variables, particularly those reflecting board characteristics. These variable groupings are discussed below.

\section{Board composition}

Board turnover may occur to replace under-performing members, though this process may be disruptive. However, turnover may also arise because members believe a company is failing and they do not wish to incur the associated reputational damage or engage in greater effort to rectify problems. With respect to Board Instability, we identify the number of resignations from the board in a given year and express this as a fraction of the number of directors at the start of the year. This variable is lagged two periods in relation to the bankruptcy outcome.

Gender diversity may bring access to a wider pool of human and social capital that reduces conflict and creates more space to address potential threats to survival, and introduces more risk averse behavior and better treasury management (Adams \& Funk, 2010). We identify the gender composition of the board and construct measures of the Ratio of Females Directors on the board or the presence of at least one female board member (Presence of Female Dummy). 
Older board members may be more experienced and better able to use that experience to adapt to market changes that may potentially threaten survival. Older directors can bring greater stability to the board and can preserve founding values (Anderson et al., 2011). We measure the age of directors in years and construct a variable capturing both the Average Age Directors and the Age Variation (CV\%) on the board (coefficient of variation). We measure average director experience by the number of days since the date of first appointment to a directorship (Average Days Experience) and to a directorship in the sector (sector experience) of the focal firm (Average Days Experience (Sector)). For each measure we sum for all current directors and divide by the number of directors.

Directors located close to the firm may be better able to monitor and to develop longstanding local trading relationships and networks that may be beneficial for firms experiencing financial distress (Berrone et al., 2010). The proximity of directors to the firm is calculated as the Ratio of Directors whose home address is in the same county as other current directors to all directors.

Directors may develop their human capital by learning from past failures and utilize this knowledge to reduce the chance of failing in subsequent ventures. On the other hand, past failures may create barriers to learning (Ucbasaran et al. 2008) and reduced reputational capital and ability to galvanize support from external parties if the firm enters distress (Wiesenfeld et al. 2008). We have identified the number of failed companies a current director has been involved with and construct a ratio of past failures to current directorships for each company (Ratio Directors Failed in Past).

Directors serving on multiple boards may deepen their skills, knowledge, and relational capital with trading partners, providing expertise to help avoid distress and, an ability to obtain extended credit terms in times of trading difficulty (Arregle, et al., 2007). On the other hand, serving on multiple boards may limit the amount of attention that directors 
can give to the focal firm. Multiple Directorships (number) are the number of directorships with other companies that the current board holds, expressed as the average number per director.

Outside directors can provide monitoring expertise that contributes to survival (Anderson \& Reeb, 2004). Alternatively, risk taking behavior may be increased as outside directors have greater sector expertise and are under pressure from external investors to enhance performance (George et al., 2005) which may reduce the likelihood of survival. Because of the legal position of directors, we are not able to distinguish between executive and non-executive directors. However, we are able to proxy Ratio Independent Directors by distinguishing directorships in the name of another company rather than an individual.

\section{Financial information}

From company accounts we use information relating to assets, retained profit measures, leverage, working capital and net worth to proxy financial risk. The accounting data can be expressed as ratio variables in levels and direction (changes). We calculate the ratio of fixed to total assets (\%) as a measure of Asset Tangibility (\%). Thus we construct financial ratios reflecting aspects of profitability (Retained Profit/Total Assets, Change in Net Worth), liquidity (Cash/Total Assets, Trade Debt/Total Assets, Trade Credit/Total Liabilities, Inventory/Total Assets) and leverage (Leverage (Debt/Total Assets)) that have been tested extensively in standard failure prediction models (Altman et al., 2010).

\section{Compliance risk}

Private family firms are typically less willing to take on outside finance as this poses a threat of loss of family control and consequently loss of SEW. As a result, the support of trading partners in providing trade credit is particularly important (Atanasova \& Wilson, 2003). As family firms can be deeply embedded in communities, reputation damage can be severe (Arregle, et al., 2007). Accordingly, family firms may be more likely to avoid getting to the 
stage of suppliers seeking legal redress. We identify the number of court actions against the company for non-payment of supplier(s) (Creditor Charge on Assets) as well as various regulatory compliance issues relating to Auditor Qualifications of accounts, auditor switching (Auditor Changes) and late filing of accounts (Accounts Filed Late) as these are well-known indicators of financial distress (Altman et al., 2010). A charge on assets is an indicator that the firm may be a risk of not servicing an unsecured loan agreement. We incorporate a dummy variable to capture whether an auditor has documented a 'severe' or 'going concern qualification'. A dummy variable capture the late filing of accounts which may indicate financial distress and finally a dummy variable indicates if the company has switched auditor in the last year.

\section{Non-financial information (Size, Age and Ownership)}

We also include non-financial data covering: board size, firm size, firm age, parentage (subsidiary or independently owned), sector, and diversification. Board Size is measured by the number of directors expressed as the natural log. Larger boards provide for the representation of different perspectives and interests and a wider set of skills, but they can also lead to coordination challenges and conflicts. Although the evidence on the relationship between board size and aspects of performance is mixed for private firms there is some support both for the notion that family firms benefit from larger boards (Gersick \& Feliu, 2013) and that family firms tend to have larger boards than non-family companies.

We use the natural log of real total assets (GDP deflated) (Log Total Assets) and the natural log of company age (from date of incorporation) (Log Age). We express asset size as a quadratic function to capture non-linearities in the relationship between asset size and bankruptcy risk $\left((\log \text { Total Assets })^{2}\right)$. Creditors rarely pursue low asset companies through the liquation process since there is little to be gained. Bankruptcy risk increases where assets are available and after a certain asset size bankruptcy risk decreases (Altman et al., 2010). 
Private limited companies can be registered as associated companies and may be subsidiaries of a single parent or larger group. Family businesses may establish a portfolio of subsidiary businesses as part of their expansion into new entrepreneurial areas but also to facilitate exit from these areas without threatening survival of the core family businesses should these activities prove unsuccessful (Sharma \& Manikutty, 2005). This type of registration is identified in official Companies House records and coded in our data-base as a dummy variable (Subsidiary (Non Family)). We include a separate dummy for family subsidiary companies because of the (ring-fencing) role that this might play in the management of new and risky ventures for family groups (Family Subsidiary). We account for economic conditions by the inclusion of macroeconomic indicators for each sector-year. We calculate the aggregate bankruptcy rate by industry sector (2-digit SIC codes) and calculate the failure rate in each sector for each year ${ }_{\mathrm{t}-1}$. We express this variable (Industry Risk) as the log odds of failure in the sector (negative values indicate higher relative risk with zero being the base line). In addition we construct dummy variables for 31 industry sectors covered in the sample as controls. We control for sector level competitive environment by utilizing the population accounting data to construct a Herfindahl-Hirschman Index of industry concentration, calculated by summing the squared market shares of each firm in the sector. High values of the HH-Index are indicative of pricing power and low competition. Family firms may diversify less than non-family firms because of their parsimonious approach to financing which means they are unwilling to take on the burden of debt to fund it and the consequent increased threat of potential loss of family control and reduction in SEW arising from the associated greater risk of financial distress (Gomez-Mejia et al., 2010). We follow Anderson et al. (2011) by identifying the number of sectors the company operates within as indicators of diversification (Diversification (No. Sectors)).

\section{Descriptive analysis}

\section{Results}


We present descriptive statistics, i.e. correlation matrix (Table 1) and means and ttests for the groups of variables of interest relating to the sub-samples of family and nonfamily firms in (Table 2). We partition the sample into family versus non-family firms. We include both continuous and binary variables and calculate, for each variable the Cohen's D size-effect statistic. Because of the large sample size, univariate analysis can produce statistics that show highly significant differences between mean values even when the magnitude of the difference is small. Cohen's D statistic provides information on the size of the difference in the mean values which we report alongside statistical significance. We apply the usual rule of thumb for calculated values of Cohen's D (0.2 is a small effect; 0.5 a medium and 0.8 a large effect). Several of our independent variables have limited range and variance (ratio fractions $0<=1$ ) and changes within a variable across the sample are not discrete (e.g. adding a female director to a board of 4 males increases the fraction from 0 to 20\%). Hence the impact within a multivariate analysis is likely more meaningful than reference to Cohen's D.

Tables 1 and 2 about here

The failure rate is significantly lower among the family firm subsample $(1.3 \%$ compared to $1.8 \%$ ). The variables reflecting board characteristics and composition in Table 2 show significant differences, statistically and by applying Cohen's D, across nine of the 11 measures. Clearly the ownership and board variables distinguish our family versus nonfamily subsamples. Family firms have a significantly higher ratio and incidence of female directorships, have older boards (although with less age variation), have more co-located directors but fewer independent directors, have fewer multiple directorships and significantly more stable boards (lower resignation rates). The directors in family firms have more sector experience than non-family firms. The results show few differences between the two samples in terms of age, size, competition and diversification but boards in family firms are smaller. 
Family firms have a higher percentage share ownership by current directors. Interestingly family firms appear to be in sectors with higher industry risk and the difference is significant between the two subsamples (although small in terms of Cohen's D, 0.2 rounded). The financial characteristics show no strong differences except for levels of debt, which are lower in family firms. There are significant differences in average director experience between family and non-family firms (although one would expect independent directors to have more experience, inflating the non-family total). Family firms have a higher level of director experience and particularly sector level experience. Family firm directors have a significantly lower experience of past failures.

\section{Family firms versus non-family firm survival}

\section{Analytical approach}

To test differences in failure propensity for the firm types, family or non-family we estimate panel logistic regression models determining bankruptcy. The sample includes 12,598 instances of bankruptcy (1.8\%) up to and including the recent recession 2007-2010. The family sub-sample has 1,970 insolvent cases (1.3\%), before controlling for size, age and sector. The data used in this study has panel properties since we have covariates for individual firms over multiple periods or until exit (failure). Although we are predicting failure in discrete time, at least one year prior to failure, it is desirable to incorporate dynamics that utilize firm specific time varying covariates and changes in the base line hazard. We use the sector bankruptcy rate (t-1) to adjust the base hazard. We follow Shumway (2001), Nam et al. (2008) and Beck et al. (1998) to construct a model which will deal with time varying covariates where estimation is undertaken with company-year observations and a limited dependent variable. The individual hazard rate of company $i$ at time $t$, is regressed on covariates representing industry risk, board characteristics and financial and non-financial information of each company $i$ at time $t$. We include a variable to 
capture the baseline hazard rate, and a constant term. Given the near population sample we have no issues with selection bias. Our dependent variable is the termination of company activity and we suggest that our covariates are not likely endogenous in relation to the binary outcome variable in line with the bankruptcy prediction literature.

The statistical significance of individual variables is tested via robust (clustered) standard errors where company identification numbers are used as the cluster criterion. Because logistic models are nonlinear, the effects of individual covariates (independent variables) on the binary dependent variable (bankruptcy risk) cannot be ascertained by reference to the estimated logistic coefficient. We provide, therefore, the average marginal effects of each of the independent variables to examine the magnitude and significance of model variables in addition to the statistical significance reported in coefficients. Accuracy of the models is reported with log likelihood statistics and information criteria.

\section{Findings}

Table 3 presents the results of estimating the models for the sample of family versus non-family firms. We compute average marginal effects of our independent variables and test for significance. We estimate five models and observe the sign, significance and magnitude of the family firm dummy variable in alternative specifications. Model 1 includes the basic variables capturing size, age, sector and ownership characteristics along with the family firm dummy variable. In Models 2 and 3, we add variables reflecting financial risk and compliance risk. Model 4 is specified to include the non-financial variables and family dummy along with board characteristics. The final model (5) includes all variables.

Table 3 about here

The models fit the data well. Model 1 has expected signs and significance across our range of variables. The family firm dummy variable is negative and strongly significant. The average marginal effect suggests a failure propensity some $27 \%(0.005 / 0.018)$ lower than the 
population failure rate. Board size has a strongly negative relationship with bankruptcy as does the level of insider ownership. Age is negative and significant confirming that firms that have survived longer are less likely to fail. There is a small negative impact of asset tangibility. We find evidence of a quadratic relationship between asset size and bankruptcy risk suggesting that low asset companies are less likely to be wound up by creditors but medium sized companies are more vulnerable to bankruptcy risk. Family firms have far fewer subsidiaries but interestingly we find a positive sign on the family firm subsidiary variable and a much smaller significant sign for non-family firms in this specification. We find no significant relationship between failure propensity and our measure of diversification but the industry risk variable is strongly significant with the expected sign. Family firms are located in sectors with higher industry risk, but nonetheless have a lower failure rate.

In Models 2 and 3 we include financial risk and compliance risk variables which are significant with the expected signs and in line with other failure prediction studies. Thus firms with higher levels of external and trade debt are more prone to failure via forced closure. Firms with positive cash balances and those able to cumulate profit reserves have a lower failure propensity. Positive changes in net worth are indicative of financial health. The subsidiary dummy variable remains positive for the family firms but negative for non-family firms. The sign and significance of the family dummy variable remain robust in this specification with only a small decrease in the average marginal effect of the dummy variable. Thus conditioning on financial performance we find a lower failure probability amongst the family subsample. Model 3 includes variable reflecting compliance risk. Firms with auditor qualifications on filed accounts and firms that change auditors have a higher failure propensity. There are positive and significant signs on creditor charges and assets and delays in filing statutory accounts. The family dummy variable in Model 3 retains its significance and the average marginal effect reduces to 0.0042 from 0.0046 in Model 1. 
These risk factors do not strongly differentiate the failure rate between family and non-family firms.

In Model 4, all variables are significant with the exception of the ratio of independent directors. Of primary interest is the significance and magnitude of the family dummy variable. The family dummy variable retains its sign and significance. However, we note that when we control for board characteristics the average marginal effect is half the scale of previous specifications (0.0049 (Model 1) and 0.0023 (Model 4)). It appears that board characteristics are important in explaining the different failure probability between the family and non-family subsamples in the data base. Board size has a negative nonlinear relation to failure probability and there is strong support for the notion that board instability and previous failures are associated with higher risks of failure. We note from the descriptive statistics that family firms have a significantly lower level of director turnover than nonfamily firms (ratio of 0.18 compared to 0.8 ). The average age of directors is negative and significant. In experiments (not reported) we found no effect for age variation.

Board diversity captured by the ratio of female directors is a negative and significant factor associated with failure likelihood. Descriptive statistics suggest that family firms have a much higher incidence of females (ratio 0.42 compared to 0.29 ) on their boards and that the family subsample has less variability in this dimension $(80 \%$ have at least one female director). Moreover, from the earlier correlation analysis, we note that the female ratio is negatively correlated with previous failures and the presence of independent directors. Firms with gender diversity appear to have a lower incidence of the other board dimensions that are associated with bankruptcy risk. Family firms have higher levels of co-location (ratio of 0.74 versus 0.63 ) and the impact of co-located directors is negative and significant in the failure model. Multiple directorships have a negative impact on survival rates but the marginal effects are very small, suggesting that the benefit of networking through multiple company 
involvements diminishes with the level of external directorships, not least because of the difficulties in balancing different duties and time across multiple ventures. Outside directorships have a positive insignificant relationship with failure risk in Model 4. Our data shows that there are significantly fewer outside directors in family firms (ratio 0.009 versus 0.041), suggesting that family firms protect the cohesion of the group by limiting the number of outside directors. The descriptive statistics show a lower incidence of previous failures among family firm directors (ratio of 0.032 versus 0.048 ). The variable capturing previous failures associated with the board has a positive and significant effect and is second in importance and magnitude to board instability.

Finally, in Model 5 the family dummy variable retains its sign and significance but the average marginal effect reduces slightly (from 0.0023 (Model 4) to 0.0020 (Model 5)), confirming our contention that board characteristics are the most important in discriminating between the failure probability of family and non-family firms.

\section{Robustness tests}

We undertake two additional analyses to test the robustness of the results.

\section{Board characteristics}

The analysis of mean differences and the Cohen's D size effect statistics in Table 2 suggest that the subsamples differ most markedly in relation to board characteristics. Moreover these characteristics are important in determining failure probability (Table 3). As a further test we estimate a logistic regression model where the dependent variable is the family firm dummy. Including size, age and sector characteristics, we investigate whether our board characteristic variables are significant in explaining differences in the family and non-family subsample. Table 4 presents the logit coefficients and average marginal effects along with the appropriate significance tests. The results confirm the subsamples differences in terms of board characteristics and there is much evidence that family firms put together and maintain 
stronger boards than the non-family sample. Family firms are more likely to have larger boards with more older and more experienced directors. They are more gender diverse than the non-family sample. The family boards have a higher ratio of co-located directors and independent directors but fewer multiple directorships. The model suggests that family boards have greater stability, lower resignation rate, and fewer past failures. As discussed, the characteristics associated with family firms in this model coincide with those associated with lower failure probabilities.

Table 4 about here

\section{Definitions of family firms}

As a second robustness test we employ stricter definitions of family firm in order to construct the family dummy variable. Two alternative family firm dummy variables are constructed using the definitions outlined above. We re-estimate the models reported in Table 3 with these alternative dummy variables and find consistent results. Because of space constraints, the results are not reported in full here but are available from the authors. The dummy variables are significant and negative with a stronger impact on failure probability. Family firms with a higher proportionate representation on the board have a lower probability of failure. This effect diminishes after family directors have 50 percent or more of the board directorships.

\section{Discussion}

We have presented the first study to compare the failure rates of family and non-family firms in the context of failure prediction models and a large (near population) sample of private companies. We establish that family firms have a significantly lower failure rate than the non-family subsample, a result which is robust to alternative definitions of family firms and in the presence of a large range of other variables. We examine, specifically, aspects of board heterogeneity and find evidence that family firms put together stronger boards at least in 
relation to failure probability. The variables measuring board characteristics are significant in determining failure probability of private companies and these variables are important in distinguishing the family and non-family subsamples. The attributes of the board that are related to lower bankruptcy risk are board size, the age and experience of directors, gender diversity, director (co)location and networks (multiple directorships). Associated with higher bankruptcy risk is board instability, previous failure experiences and albeit weakly, the ratio of independent directors. These findings open up a number of opportunities for further research.

First, our finding that family firm ownership is highly significantly associated with firm survival suggests that the family brings in different kinds of resources to help survival. There is a need for further conceptual and empirical research on which specific resources are key to survival. Prior corporate governance research generally has tended to focus only on board size and independent directors in listed corporations (Fich \& Slezak, 2008). Other work has examined turnover of boards in listed firms already in distress and has noted both high exit rate and difficulties in recruiting new members with expertise to restructure the firm (Ayotte, Hotchkiss \& Thorburn, 2013). Our analysis extends these studies by showing that it is also important to consider what happens to board changes in averting bankruptcy and in a different context. Family firms exhibit greater board stability and it is the ability of family firms to hold together in times of difficulty that is important in avoiding bankruptcy. Additional analysis of how family and non-family firms manage stability and the human and social capital that changes with instability seems warranted.

Director proximity to the firm seems important for managing bankruptcy risk. By definition, family members are in close communication and likely have more informal interactions with other board members and the wider family group beyond our measure of colocation. Further research might examine how this process works. 
Family firms have fewer outside directors compared to non-family firms. This variable is weakly positive in the bankruptcy risk models again emphasizing the relative importance of hands on day-to-day involvement of directors in periods of distress. Additional analysis is warranted of the involvement of outside directors in terms of, for example, whether they encourage riskier activities but are reluctant to become closely engaged in resolving problems of distress, or whether they are unable to intervene successfully to address family conflicts that lead to distress.

Family firms have more female directors and lie at the 'gender diverse' end of the spectrum of private firms. Gender diversity is strongly associated with reducing bankruptcy risk in the estimated models. Moreover, there appears to be an interesting dynamic between this diversity and other board characteristics that is worthy of further investigation. For instance our correlation analysis suggests that firms with higher levels of gender diversity coincidentally have better board stability (less conflict), fewer previous failures and fewer independent directors.

Family firms are likely to have older and more experienced boards, again attributes associated with lower failure risk. An area for further exploration is whether and how family directors draw on the experience of the wider family group. Through this mechanism family firms' may have a 'built-in diversity' in terms of age, experience and gender that functions through the likely interactions between directors and the family members not represented on the board. As yet, the resources provided by these interactions are little understood.

The family subsample has a lower incidence of past failures amongst their directors. For family firms the potentially positive learning effects of past failures may be offset by the reputational damage within their networks. This reputational damage may be particularly acute for family businesses that have an interest in protecting the family reputation and take 
action to mitigate adverse consequences of previous failures. Further direct analysis of the loss of human and social capital resource associated with prior director failure is warranted.

The second suggestion emerging from our findings is that family firms construct stronger boards comprising members with greater human and social capital and there is a need for further research on what drives the process of developing these stronger boards and how these boards interact with other factors. In the context of calls to develop multiple theoretical perspectives in understanding the behavior of family firms (Bammens et al., 2011; Corbetta \& Salvato, 2004), this suggests opportunities to bring together resource-based perspectives on the role of boards (Huse, 2005) with the different dimensions of SEW (Berrone et al., 2012) to obtain insight about their influence on the survival of family and non-family firms. For example, board members may be recruited who will provide a pool of human and social capital resources to protect SEW in family firms in terms of maintaining ownership and control but also prevent the extinguishing of SEW because of the loss of control associated with firm failure. In contrast, in non-family firms board composition may be associated with human and social capital to preserve purely financial survival. As yet there is a lack of understanding of which of the elements and which combinations of board composition examined here play a more effective role in protecting SEW versus pure financial survival in family and non-family firms.

Further aspects of interactions concern the potential for interdependence between corporate governance mechanisms. Additional research might seek to explore these interdependencies. Studies might usefully examine whether and to what extent different director characteristics act as complements or substitutes. For example, in our study the female ratio is negatively correlated with previous failure experience of directors. There may also be interdependencies between board characteristics and the nature of influence by family members not part of the board. Exploration of these interdependencies may require either 
survey or case studies approaches to access data not available in public records. An additional dimension relates to the interaction between board composition and the nature of financing, in particular the role of debt. Further research might usefully theorize and empirically examine in more depth the differences between boards in family and non-family firms with respect to these financing decisions and how they impact survival.

Third, an important issue emerging from our analysis is that there may be endogeneity between family ownership and firm survival. On one hand, families may sell the firm if they perceive it does not have a positive long term future. As a result, analysis may potentially be biased if the sample does not contain these firms as they have already been sold. On the other hand, inertia and emotional attachment by families may mean that family firms whose survival is under threat are held onto longer than they should be. Further research could seek to adjust for endogeneity issues, although there are challenges to doing this in a logistic estimation environment. Alternatively, more qualitative research could explore how family firms decide whether and when to dispose of businesses close to distress.

Fourth, although we study director characteristics and financial aspects for a population of firms, we focused solely on private family firms in the UK and the findings may not be applicable to different institutional contexts. Additional research on board characteristics between family and non-family firms among listed corporations and IPOs, and in non-Anglo American contexts would be welcome.

Fifth, our focus was on board composition but further research using different approaches is needed to examine the nature of board processes such as the role of board meetings and committees as well as the extent to which board decision making was centralized (Hatum \& Pettigrew, 2004), when family businesses face conditions of distress or crisis. For example, studies could explore how SEW preservation is addressed by family board members in such circumstances and how family non-board members influence this 
process. Further, examination of the process could also address how outside directors and directors with different types of experience influence the family firm's strategy to deal with distress and ensure survival. What is the nature of the conflicts in this process and how are they resolved? For example, are outside directors or women board members better able to resolve conflicts that might arise?

Sixth, our focus has been to compare family and non-family firms. Recent literature has pointed to the heterogeneity of family businesses (Bammens, et al., 2011). Further research is needed to examine the variations within family businesses and their boards and the implications for firm survival. Relatedly, although we undertook some robustness checks using alternative definitions of family firms, our use of archival data precluded us from incorporating some of the perceptual variants in Westhead and Cowling (1998) which was based on survey data. Further research may seek to consider the potential impact of other definitional variants on survival.

Seventh, family firm survival may be influenced by whether the founder or subsequent generations are running the business. Although we proxied generation by age, we were unable to measure the generation directly. There is some evidence of differences in boards between generations and we know about attrition rates of family firms across generations, but we know little about how differences in the composition of expertise on the board across generations may contribute to whether the firm survives or not.

Eighth, our focus was on the role of board composition in whether family firms enter bankruptcy. Preservation of SEW issues may also influence whether the family is more likely to engage in efforts to reconfigure the business so that it can emerge successfully from bankruptcy than might be the case for non-family firms. Further research might usefully compare the outcomes of bankruptcy processes for these different types of firms. For example, does the firm re-emerge as a slimmed down viable entity or broken up? Does the 
family retain some involvement or does an entirely new set of owners emerge, possibly in the form of a buyout by non-family managers?

Ninth, we find that while within the full sample of family and non-family firms, subsidiaries were significantly less likely to fail, within the family firm only sample the coefficient on subsidiaries was insignificant. Although it was beyond the scope of this paper, future research might usefully examine differences in strategies in the establishment of subsidiaries by family and non-family firms. For example, do family firms create subsidiaries as a means to ring fence high risk activities, which may include the development of new product areas, to protect SEW tied up in the main family business. Additional qualitative and quantitative research is also needed to examine the process of creating new subsidiaries by family firms and the effects on survival and risk of creating subsidiary structures versus alternative organizational approaches.

Finally, our study suggests implications for practice and policy. There may be benefits from improving local director networks and mentoring schemes. Measures to enhance gender balance on boards may also have a contribution to make. Our finding that family firms are more diversified than non-family firms in terms of the number of sectors in which they operate is intriguing but may reflect strategies whereby the next generation of family members is encouraged to pursue new ideas that may benefit the firm in the longer run. Further, diversification may also be related to reducing failure risk.

In sum, our analysis has begun to open a novel research agenda that extends the focus hitherto on the survival of firms as family firms to consideration of the role of boards in the survival of family firms as viable entities. 


\section{References}

Adams, R. \& Funk, P. (2010). Beyond the glass ceiling: Does gender matter? Finance Working Paper Series, No.273/2010. European Corporate Governance Institute

Altman, E., Wilson, N. \& Sabato, G. (2010). The value of non-financial information in SME risk management. Journal of Credit Risk, 6(2), 1-33.

Anderson, R., \& Reeb, D. (2004). Board composition: Balancing family influence in S\&P 500 firms. Administrative Science Quarterly, 49, 209-237.

Anderson, R.C., Reeb, D.M., Upadhyay, A., \& Zhao, W. (2011).The economics of director heterogeneity. Financial Management, 40(1), 5 - 38.

Arregle, J-L, Hitt, M., Sirmon, D.G. \& Very, P. (2007). The development of organizational social capital: Attributes of family firms. Journal of Management Studies, 44(1), 73-95.

Atanasova, C.V. \& Wilson N. (2003). Borrowing constraints and the demand for trade credit: Evidence from panel data. Managerial and Decision Economics, 24(6-7), 503-514.

Ayotte, K., Hotchkiss, E., \& Thorburn, K. (2013). Governance in financial distress and bankruptcy. Ch.22 in Wright, M., Siegel, D., Keasey, K., \& Filatochev, I. (eds) The Oxford Handbook of Corporate Governance. Oxford: OUP. pp. 489-514.

Bammens, Y., Voordeckers, W., \& van Gils A. (2011). Boards of directors in family businesses: A literature review and research agenda. International Journal of Management Reviews, 13(2), 134-152.

Beck, N., Katz, J. \& Tucker, R. (1998). Taking time seriously: Time-series-crosssection analysis with a binary dependent variable. American Journal of Political Science, 42, 1260-1288.

Berrone, P., Cruz, C., Gomez-Mejia, L., \& Larraza-Kintana, M. (2010). Socioemotional wealth and corporate responses to institutional pressures: Do family-controlled firms pollute less? Administrative Science Quarterly, 55(1), 82-113.

Berrone, P., Cruz, C., \& Gomez-Mejia, L. (2012). Socioemotional Wealth in family firms: Theoretical dimensions, assessment approaches, and agenda for future research. Family Business Review, 25(3), 258-279.

Carney, M. (2005). Corporate governance and competitive advantage in family-controlled firms. Entrepreneurship Theory and Practice, 29(3), 249-265.

Chrisman, J.J., Chua, J.H. \& Zahra, S.A. (2003). Creating wealth in family firms through managing resources: Comments and extensions. Entrepreneurship Theory and Practice, 27(4), 359-365. 
Chrisman, J.J., Chua, J.H. \& Litz, R.A. (2004). Comparing the agency costs of family and non-family firms: Conceptual issues and exploratory evidence. Entrepreneurship Theory and Practice, 28(4), 335-354.

Colli, A. (2012). Contextualizing performances of family firms: The perspective of business history. Family Business Review, 25(3), 243-257.

Corbetta, G., \& Salvato, C. A. (2004). The board of directors in family firms: one size fits all? Family Business Review, 17(2), 119-134.

Farrell, K., \& Hersch, P. (2005). Additions to corporate boards: the effect of gender. Journal of Corporate Finance, 11(1-2), 85-106.

Fich, E. \& Slezak, S. (2008). Can corporate governance save distressed firms from bankruptcy? An empirical analysis. Review of Quantitative Financial Accounting, 30(2), 225251.

Gedajlovic, E., \& Carney, M. (2010). Markets hierarchies and families: Toward a transactions cost theory of the family firm. Entrepreneurship Theory and Practice, 34(6), $1145-1171$.

Gedajlovic, E., Carney, M., Chrisman, J.J. \& Kellermanns, F.W. (2012). The adolescence of family firm research: Taking stock and planning for the future. Journal of Management, 38(4), 1010-1037.

George, G., Wiklund, J. \& Zahra, S. (2005). Ownership and the internationalization of small firms. Journal of Management, 31(2), 210-33.

Gersick, K. \& Feliu, N. (2013). Governing the family enterprise: Practices, performance, and research. Ch. 11 in Melin, L., Nordqvist, M. \& Sharma, P. (eds). The SAGE Handbook of Family Business. London: Sage, forthcoming.

Goel, S., Jussila, I. \& Ikäheimonen, T. (2013). Governance in Family Firms: A Review and Research Agenda. Ch. 12 in Melin, L., Nordqvist, M. \& Sharma, P. (eds). The SAGE Handbook of Family Business. London: Sage, forthcoming.

Gomez-Mejia, L.R., Haynes, K.T., Nunez-Nickel, M., Jacobson, K.J.L., \& Moyano-Fuentes, J. (2007). Socioemotional wealth and business risks in family-controlled firms: Evidence from Spanish olive oil mills. Administrative Science Quarterly, 52(1), 106-137

Gomez-Mejia L.R., Makri M., \& Larraza-Kintana M. (2010). Diversification decisions in family-controlled firms. Journal of Management Studies, 47(2), 223-252.

Hatum, A. \& Pettigrew, A. (2004). Adaptation under environmental turmoil: Organizational flexibility in family owned firms. Family Business Review, 17(3), 237- 258.

Hiebl, M. (2013). Risk taking in family firms: What do we really know? Journal of Risk Finance, 14(1), 49-70. 
Huse, M. (2005). Accountability and creating accountability: A framework for exploring behavioural perspectives of corporate governance. British Journal of Management, 16 (Suppl.), 65-79.

Kellermanns, F. W., \& Eddleston, K. (2004). Feuding families: When conflict does a family firm good. Entrepreneurship Theory and Practice, 28(3), 209-228.

Kellermanns, F.W., Eddleston, K.A., Barnett, T., \& Pearson, A. (2008). An exploratory study of family member characteristics and involvement: Effects on entrepreneurial behavior in the family firm. Family Business Review, 21(1), 1-14.

Miller, D., \& Le Breton-Miller, I. (2003). Challenge versus advantage in family business. Strategic Organization, 1(1), 127-134.

Miller, D., Le Breton-Miller, I. \& Lester, R. (2010). Family ownership and acquisition behaviour in publicly traded companies. Strategic Management Journal, 31(2), 201-223.

Morck, R. (2003). Agency problems in large family business groups. Entrepreneurship Theory and Practice, 27(4), 367-383.

Nam, C.W., Kim, T., Park, N. \& Lee, H. (2008). Bankruptcy prediction using a discrete-time duration model incorporating temporal and macroeconomic dependencies. Journal of Forecasting, 27, 493-506.

Schulze, W. S., Lubatkin, M. H., \& Dino, R. N. (2003).Toward a theory of agency and altruism in family firms. Journal of Business Venturing, 18(4), 473-490.

Sharma, P., \& Manikutty, S. (2005). Strategic divestments in family firms: Role of family structure and community culture. Entrepreneurship Theory and Practice, 29(3), 293-311.

Shumway, T. (2001). Forecasting bankruptcy more accurately: A simple hazard model. Journal of Business, 74, 101 - 124

Sirmon, D.G. \& Hitt, M.A., (2003). Managing resources: Linking unique resources, management, and wealth creation in family firms. Entrepreneurship Theory and Practice, 27(4), 339-358.

Ucbasaran, D., Westhead, P., \& Wright M. (2008), Opportunity identification and pursuit: Does an entrepreneur's human capital matter? Small Business Economics, 30(2), 153-173.

Villalonga, B. \& Amit, R. (2006). How do family ownership, control and management affect firm value? Journal of Financial Economics, 80(2), 385-417.

Westhead, P., \& Cowling, M. (1998). Family firm research: The need for a methodology rethink. Entrepreneurship Theory and Practice, 23(1), 31-56.

Wiesenfeld, B. M., Wurthmann, K. A. \& Hambrick, D. C. (2008). The stigmatization and devaluation of elites associated with corporate failures: A process model. Academy of Management Review, 33(1), 231-251. 
Wright, M. \& Kellermans, F. (2011). Family firms: A research agenda and publication guide. Journal of Family Business Strategy, 2(4), 187-198.

Yu, A., Lumpkin, G., Sorenson, R. \& Brigham, K. (2012). The landscape of family business outcomes: A summary and numerical taxonomy of dependent variables. Family Business Review, 25(1), 33-57.

Zahra, S. A. (2010). Harvesting family firms' organizational social capital: A relational perspective. Journal of Management Studies, 47(2), 345-366.

Zellweger, T. M., Nason, R. S., Nordqvist, M., \& Brush, C. G. (2013). Why do family firms strive for nonfinancial goals? An organizational identity perspective. Entrepreneurship Theory and Practice. Forthcoming. 
Table 1: Correlation Matrix for Continuous Variables

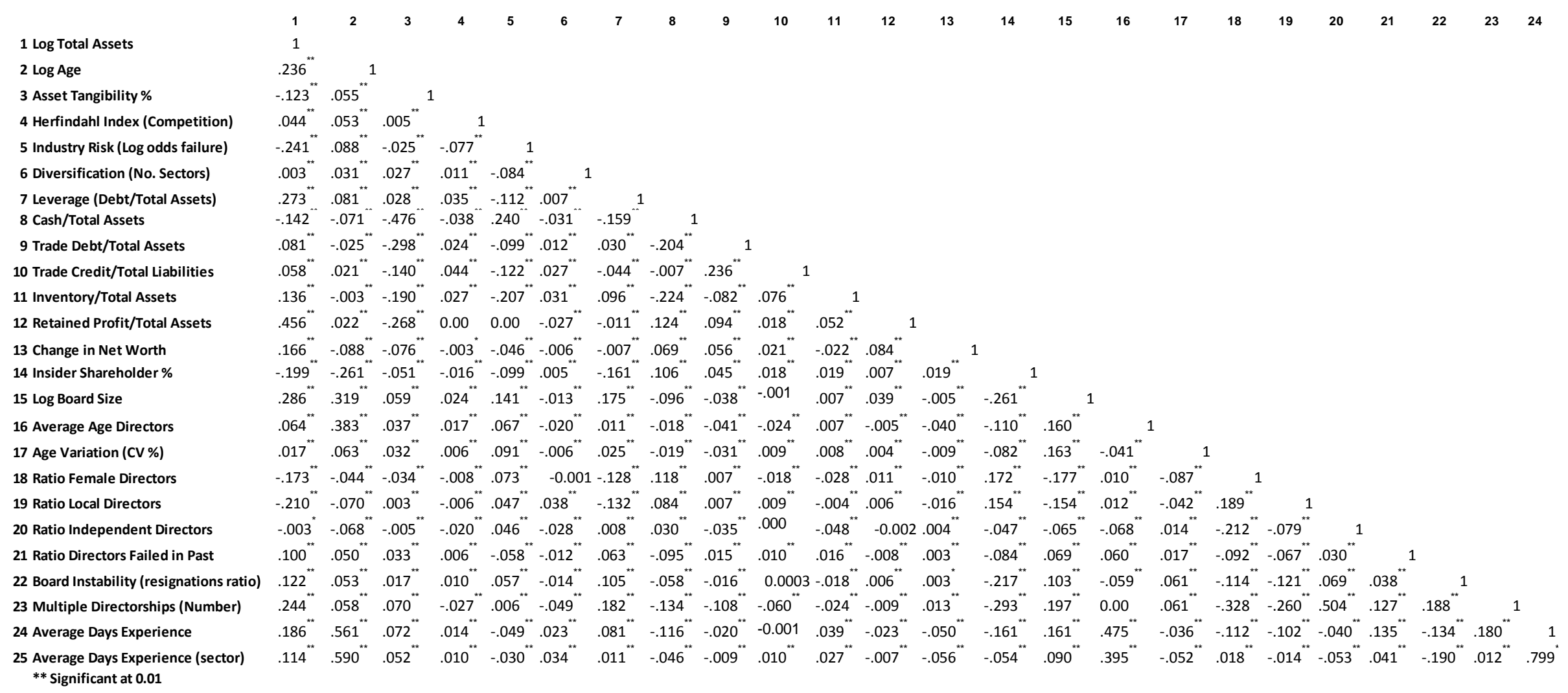


Table 2. T-tests and Cohen's D Size-effects for family versus non-family firms

\begin{tabular}{|c|c|c|c|c|c|}
\hline & \multicolumn{4}{|c|}{ All Companies } \\
\hline & & Family & Non-Family & Significance & Cohen's D \\
\hline \multicolumn{6}{|c|}{ Variables } \\
\hline \multirow[t]{5}{*}{ Size, Age, Ownership } & Log Total Assets & 10.630 & 10.851 & 0.000 & 0.064 \\
\hline & Log Age & 2.1612 & 2.1741 & 0.000 & 0.017 \\
\hline & Asset Tangibility \% & 29.057 & 29.563 & 0.000 & 0.014 \\
\hline & Insider Shareholder \% & 0.817 & 0.385 & 0.000 & 1.024 \\
\hline & Log Board Size & 1.313 & 1.374 & 0.000 & 0.208 \\
\hline \multirow[t]{3}{*}{ Industry Sector } & Herfindahl Index (Competition) & 259.050 & 256.112 & 0.115 & 0.005 \\
\hline & Industry Risk (Log odds failure) & -0.004 & 0.191 & 0.000 & 0.279 \\
\hline & Diversification (No. Sectors) & 1.229 & 1.194 & 0.000 & 0.064 \\
\hline \multirow[t]{7}{*}{ Financial Risk } & Leverage (Debt/Total Assets) & 0.041 & 0.088 & 0.000 & 0.165 \\
\hline & Cash/Total Assets & 0.315 & 0.303 & 0.000 & 0.036 \\
\hline & Trade Debt/Total Assets & 0.171 & 0.153 & 0.000 & 0.071 \\
\hline & Trade Credit/Total Liabilities & 0.152 & 0.146 & 0.000 & 0.024 \\
\hline & Inventory/Total Assets & 0.091 & 0.075 & 0.000 & 0.080 \\
\hline & Retained Profit/Total Assets & -1.299 & -1.865 & 0.000 & 0.053 \\
\hline & Change in NetWorth & 0.594 & 0.482 & 0.000 & 0.026 \\
\hline \multirow[t]{5}{*}{ Compliance Risk } & Auditor Qualification & 0.002 & 0.007 & 0.000 & 0.066 \\
\hline & Auditor Change & 0.051 & 0.067 & 0.000 & 0.066 \\
\hline & Accounts Filed Late & 10.447 & 11.999 & 0.000 & 0.037 \\
\hline & Creditor Charge on Assets & 0.033 & 0.047 & 0.000 & 0.066 \\
\hline & Court Judgments & 0.015 & 0.022 & 0.000 & 0.027 \\
\hline \multicolumn{6}{|l|}{ Board Characteristics } \\
\hline & Average Age Directors & 50.873 & 49.189 & 0.000 & 0.172 \\
\hline & Age Variation (CV \%) & 11.256 & 13.397 & 0.000 & 0.196 \\
\hline & Ratio Female Directors & 0.423 & 0.288 & 0.000 & 0.492 \\
\hline & Presence of Female (Dummy) & 0.814 & 0.585 & 0.000 & 0.485 \\
\hline & Ratio Local Directors & 0.742 & 0.603 & 0.000 & 0.336 \\
\hline & Ratio Independent Directors & 0.009 & 0.041 & 0.000 & 0.276 \\
\hline & Ratio Directors Failed in Past & 0.032 & 0.048 & 0.000 & 0.111 \\
\hline & Board Instability (resignations ratio) & .0182 & .0801 & 0.000 & 0.335 \\
\hline & Multiple Directorships (Number) & 4.465 & 23.425 & 0.000 & 0.214 \\
\hline & Average Days Experience & 3187.07 & 3015.72 & 0.000 & 0.106 \\
\hline & Average Days Experience (sector) & 2918.55 & 2591.22 & 0.000 & 0.213 \\
\hline Dependent variable & Failure Rate & 0.0131 & 0.0189 & 0.000 & \\
\hline
\end{tabular}

Note: Cohen's d provides a benchmark for the size-effect of the mean differences, whereby 0.2 equates to a small effect, 0.5 equates to a medium effect, and effects larger than 0.8 equate to large effects 
Table 3. Discrete time hazard models determining company failure.

The dependent variable is a dummy variable that indicates whether a company goes insolvent in one particular analysis year ( 1 =insolvent). Model 1 includes the range of control variables age, size and ownership controls, industry sector, industry risk (basic controls).A dummy variable representing family or non-family firm is included in all specifications. Board characteristics are included as independent variables. Baseline hazard is the industry risk. Model 1 includes basic controls and the family dummy variable. Models 2 and 3 include additional levels of control (financial risk and compliance risk). Model 4 is estimated to include basic controls and our independent variables, board characteristics. Model 5 is the full model inclusive of independent and all control variables. One way cluster robust standard errors are calculated for logit coefficients. Standard errors for the estimates of the average marginal effects are computed using the delta method. The delta method uses a first-order Taylor series to obtain a linear approximation of a non-linear function

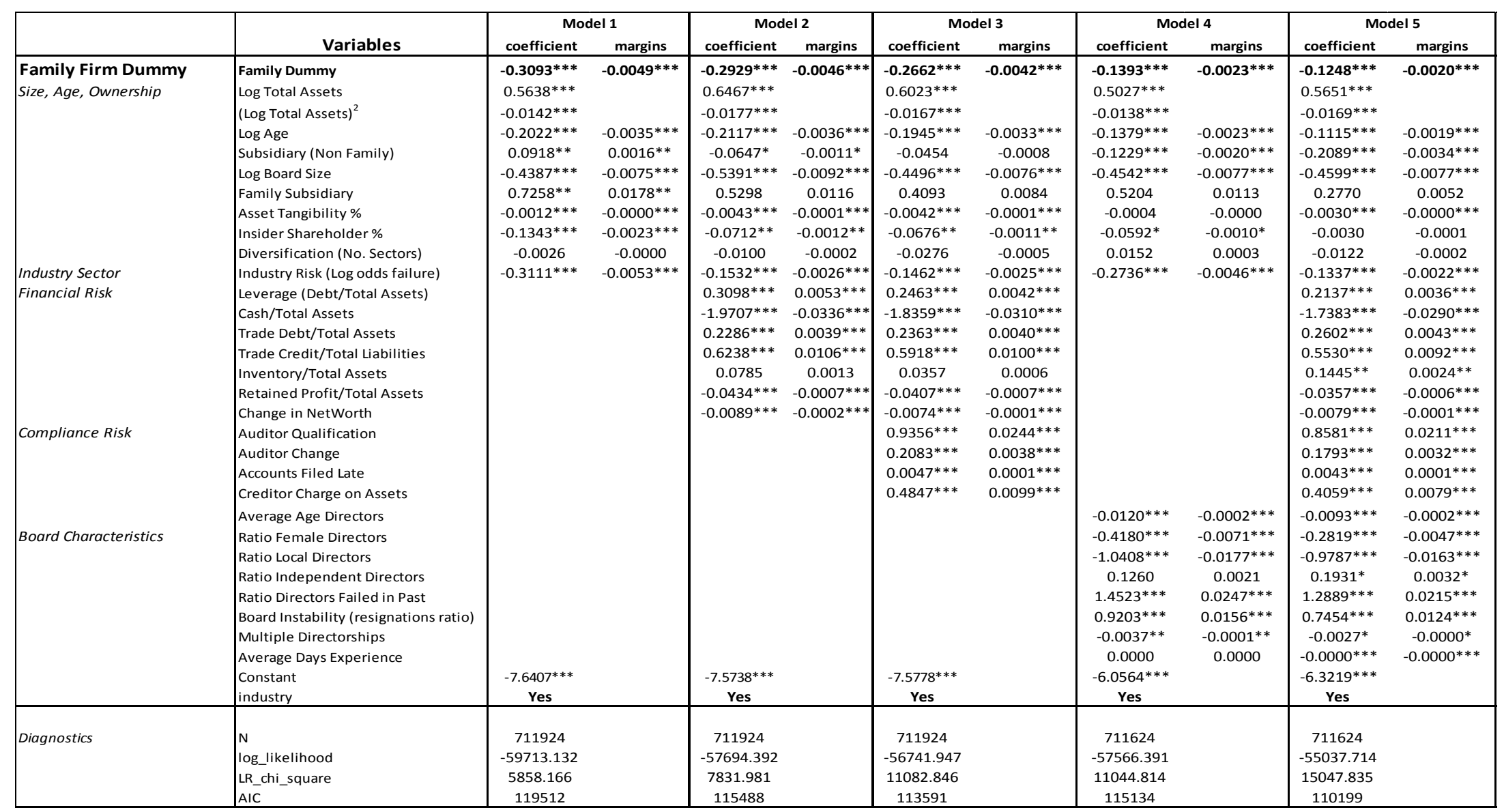

\footnotetext{
$*, * *, * * *$ significant at $\mathrm{P}<0.05, \mathrm{P}<0.01$, and $\mathrm{P}<0.001$.
} 
Table 4. Logistic Regression: Board Characteristics Associated with Family Firms

The dependent variable is a dummy variable that indicates whether a company is a family firm or not $(1,0)$. We control for size, age, sector and sector risk and include the range of variables reflecting board

characteristics (independent variables). One way cluster robust standard errors are calculated for logit coefficients. Standard errors for the estimates of the average marginal effects are computed using the delta method.

The delta method uses a first-order Taylor series to obtain a linear approximation of a non-linear function.

\begin{tabular}{|l|l|ll|}
\hline \multicolumn{1}{|c|}{ Logit : family firm=1 } & \multicolumn{1}{|c|}{ Variables } & coefficient & margins \\
\hline Size, Age, Ownership & Log Total Assets & $0.0264^{* * *}$ & \\
Industry Sector & Log Age & $-0.1849^{* * *}$ & \\
Board Characteristics & Industry Risk (Log odds failure) & $-0.5551^{* * *}$ & \\
& Board Size & $0.1957^{* * *}$ & $0.0288^{* * *}$ \\
& Average Age Directors & $0.0148^{* * *}$ & $0.0022^{* * *}$ \\
& Ratio Female Directors & $1.2146^{* * *}$ & $0.1790^{* * *}$ \\
& Ratio Local Directors & $0.4564^{* * *}$ & $0.0673^{* * *}$ \\
& Ratio Independent Directors & $0.2824^{* * *}$ & $0.0416^{* * *}$ \\
& Ratio Directors Failed in Past & $-0.4705^{* * *}$ & $-0.0693^{* * *}$ \\
& Board Instability (resignations ratio) & $-1.8701^{* * *}$ & $-0.2756^{* * *}$ \\
& Multiple Directorships & $-0.0806^{* * *}$ & $-0.0119^{* * *}$ \\
& Average Days Experience & $0.0002^{* * *}$ & $0.0000^{* * *}$ \\
& Constant & $-3.1047^{* * *}$ & \\
\hline \multirow{3}{*}{ Diagnostics } & industry Dummies & Yes & \\
& N & 711650 & \\
& Nog_likelihood & -320655.384 & \\
& LR_chi_square & 29866.793 & \\
& & & \\
\hline
\end{tabular}

